Article

\title{
Synthesis, Crystal Structures, and Properties of a New Supramolecular Polymer Based on Mixed Imidazole and Carboxylate Ligands
}

\author{
Mei-An Zhu, Shan-Shan Shi, Shuai-Shuai Han, Jin Mei and Shui-Sheng Chen * \\ College of Chemistry \& Chemical Engineering, Fuyang Normal University, Fuyang 236041, China; \\ zhumeian2017@163.com (M.-A.Z.); shishanshanshan@126.com (S.-S.S.); shuisheng2001@tom.com (S.-S.H.) \\ njncwater@163.com (J.M.) \\ * Correspondence: chenss@fync.edu.cn; Tel.: +86-558-2595836 \\ Academic Editor: Shujun Zhang \\ Received: 5 June 2017; Accepted: 2 July 2017; Published: 13 July 2017
}

\begin{abstract}
One new coordination polymer, namely, $\left[\mathrm{Cd}_{3}\left(\mathrm{H}_{2} \mathrm{~L}\right)_{3}(\mathrm{Pza})_{2}\left(\mathrm{H}_{2} \mathrm{O}\right)_{2}\right]_{n}(\mathbf{1})$ was synthesized by the reaction of $\mathrm{Cd}\left(\mathrm{NO}_{3}\right)_{2} \cdot 4 \mathrm{H}_{2} \mathrm{O}$ with 1,4-di $\left(1 \mathrm{H}\right.$-imidazol-4-yl)benzene $\left(\mathrm{H}_{2} \mathrm{~L}\right)$ and 3,5-pyrazoledicarboxylic acid $\left(\mathrm{H}_{3}\right.$ pza) and characterized by single-crystal $\mathrm{X}$-ray diffraction, IR spectroscopy, elemental analysis, and powder X-ray diffraction (PXRD). The $\mathrm{H}_{3}$ pza ligand was completely deprotonated to pza ${ }^{3-}$, which bridged the $\mathrm{Cd}^{2+}$ to form one-dimensional (1D) chain. The adjacent 1D chains were further linked into the two-dimensional (2D) layer by the linear $\mathrm{H}_{2} \mathrm{~L}$ ligands. The weak interaction, including hydrogen bonds and $\pi-\pi$ stacking interactions, extends the 2D layers into three-dimensional (3D) supramolecular polymer. Complex 1 shows intense light blue emission in the solid state at room temperature.
\end{abstract}

Keywords: coordination polymer; 2D layer structure; structural characterization

\section{Introduction}

In the recent years, rational design and successful construction of metal-organic frameworks (MOFs) has become an expanding research topic in the fields of synthetic chemistry and materials science not only because of their intriguing variety of architectures and captivating topologies but also their potentially multi-field applications in numerous areas in fluorescence, gas adsorption/separation, magnetic properties, electrochemistry, catalysis, and so on [1-8]. The MOFs possessing versatile structures and desired properties are mainly dependent on the appropriate organic linkers $[9,10]$, and the external synthesis conditions such as $\mathrm{pH}$ values, molar ratio of reactants, reaction temperatures, solvent system, and counter anions play important roles in deciding the resulting architectures [11-13]. Up to now, the $\mathrm{N}$ - or O-donor organic ligands have been employed extensively to construct functional coordination polymers [14-16]. Particularly, the N-donor compounds such as imidazole, pyrazole, triazole, and tetrazole can exhibit flexible coordination modes and afford more predictable coordination modes, as a result, these types of ligands have been extensively employed to construct diverse complexes.

In our previous studies, we have elaborately designed the series of 4-imidazole-containing imidazole ligands such as 1,4-di( $1 H$-imidazol-4-yl)benzene and 1,3,5-tri( $1 H$-imidazol-4-yl)benzene and successfully synthesized the porous MOFs based on the metal-imidazolate building units, showing favorable gas adsorption, especially selective adsorption property for $\mathrm{CO}_{2}$ molecules $[17,18]$. Considering that a mixed ligand assembly strategy incorporating imidazole-containing ligands and polycarboxylates can effectively construct diverse topological networks, we have employed the 4-imidazolyl-containing ligands to build some novel frameworks together with different carboxylate ligands $[19,20]$. 
As an extension of our previous work, we apply the 4-imidazoly-containing ligand of 1,4-di(1H-imidazol-4-yl)benzene to build new coordination polymer together with dicarboxylic acid of a 3,5-pyrazoledicarboxylic acid containing pyzole parent nucleus. Here, we report the synthesis and crystal structure of a new coordination polymer of $\left[\mathrm{Cd}_{3}\left(\mathrm{H}_{2} \mathrm{~L}\right)_{3}(\mathrm{Pza})_{2}\left(\mathrm{H}_{2} \mathrm{O}\right)_{2}\right]_{\mathrm{n}}(\mathbf{1})$ obtained by the reaction of these mixed ligands with $\mathrm{CdCl}_{2} \cdot 2 \cdot 5 \mathrm{H}_{2} \mathrm{O}$ under hydrothermal condition.

\section{Results and Discussion}

\subsection{Structural Description of $\left[\mathrm{Cd}_{3}\left(\mathrm{H}_{2} \mathrm{~L}\right)_{3}(\mathrm{Pza})_{2}\left(\mathrm{H}_{2} \mathrm{O}\right)_{2}\right]_{n}(\mathbf{1})$}

Single crystal X-ray diffraction analysis reveals that $\left[\mathrm{Cd}_{3}\left(\mathrm{H}_{2} \mathrm{~L}\right)_{3}(\mathrm{Pza})_{2}\left(\mathrm{H}_{2} \mathrm{O}\right)_{2}\right]_{n}$ crystallizes in triclinic $P-1$ space group. The asymmetric unit of 1 contains two crystallographically independent $\mathrm{Cd}(\mathrm{II})$ atoms, one and a half $\mathrm{L}$ ligands, one completely deprotonated $\mathrm{pza}^{3-}$, and one coordinated water molecule. It should be mentioned that both $\mathrm{H}_{2} \mathrm{~L}$ and $\mathrm{H}_{3}$ pza have active hydrogen atoms in the heterocyclic rings, and can deprotonate to be anion ligands, but the $\mathrm{H}_{2} \mathrm{~L}$ keeps a neutral ligand and three active protons from the carboxyl groups and pyzole of $\mathrm{H}_{3}$ Pza completely deprotonated to be $\mathrm{pza}^{3-}$, in this sense, the complex keep neutral. As shown in Figure 1, the Cd1 center is sitting on an inversion center and has octahedral coordination geometry with $\mathrm{N}_{4} \mathrm{O}_{2}$ binding set coordinated by two pairs of atoms $\left(\mathrm{O}(4), \mathrm{N}(7)\right.$ and $\mathrm{O}(4 \mathrm{~A}), \mathrm{N}(7 \mathrm{~A})$ ) from two distinct pza $^{3-}$ ligands and another two nitrogen atoms (N5, N5A) from two other $\mathrm{H}_{2} \mathrm{~L}$ ligands. The $\mathrm{Cd}-\mathrm{N}$ distances are 2.299(2) and 2.3449 (19) $\AA$ while the $\mathrm{Cd}-\mathrm{O}$ distance is 2.3324 (18) $\AA$, and the coordination angles around $\mathrm{Cd}(1)$ are in the range of $73.27(6)^{\circ} \sim 180.0^{\circ}$ (Table 1). In this complex, both of carboxyl group in $\mu_{1}-\eta^{1}: \eta^{0}$-monodentate coordination mode from $\mathrm{pza}^{3-}$ ligand together with adjacent $\mathrm{N}$ atom chelate with one $\mathrm{Cd}(\mathrm{II})$ atom, in return, each pza ${ }^{3-}$ ligand acts as a $\mu_{2}$-bridge to link two $\mathrm{Cd}(\mathrm{II})$ atoms. This connection makes a one-dimensional (1D) chain of $\left[\mathrm{Cd}_{3}(\mathrm{Pza})_{2}\right]$ (Figure 2). These adjacent $1 \mathrm{D}$ chains are connected by linear $\mathrm{H}_{2} \mathrm{~L}$ ligand into two-dimensional (2D) layer structure (Figure 3). Particularly, the NH or N atom of imidazolyl groups and the carboxyl group, can act as hydrogen bonding donor or acceptor, thus easily benefiting the construction of supramolecular structures. Therefore, there exists rich hydrogen bonding interaction in this complex, and the $\mathrm{N}-\mathrm{H} \cdots \mathrm{O}$ and $\mathrm{C}-\mathrm{H} \cdots \mathrm{O}(\mathrm{N}(2) \cdots \mathrm{O}(1) 2.738(3) \AA, \mathrm{N}(2)-\mathrm{H}(2 \mathrm{~A}) \cdots \mathrm{O}(1)$ $160^{\circ} ; \mathrm{N}(4) \cdots \mathrm{O}(3) 2.744(3) \AA, \mathrm{N}(4)-\mathrm{H}(4 \mathrm{~A}) \cdots \mathrm{O}(3) 176^{\circ} ; \mathrm{N}(6) \cdots \mathrm{O}(3) 2.745(3) \AA, \mathrm{N}(6)-\mathrm{H}(6) \cdots \mathrm{O}(3) 161^{\circ}$; $\mathrm{C}(4) \cdots \mathrm{O}(1) 3.071(3) \AA, \mathrm{C}(4)-\mathrm{H}(4) \cdots \mathrm{O}(1) 117^{\circ}$ ) hydrogen bond exist among the 2D layers highlighted in pink dotted lines (Table 2 ), moreover, the classic weak $\pi-\pi$ stacking interactions also exist between the two neighboring 2D layers. The two imidazole rings of the $\mathrm{H}_{2} \mathrm{~L}$ ligands between the adjacent 2D layers are parallel and are separated by a centroid-centroid distance of $3.86 \AA$, indicating the presence of $\pi-\pi$ stacking interactions [21]. Generally, the weak interactions of hydrogen bonding and $\pi-\pi$ stacking interactions further link the 2D layers into three-dimensional (3D) supramolecular polymer (Figure 4).

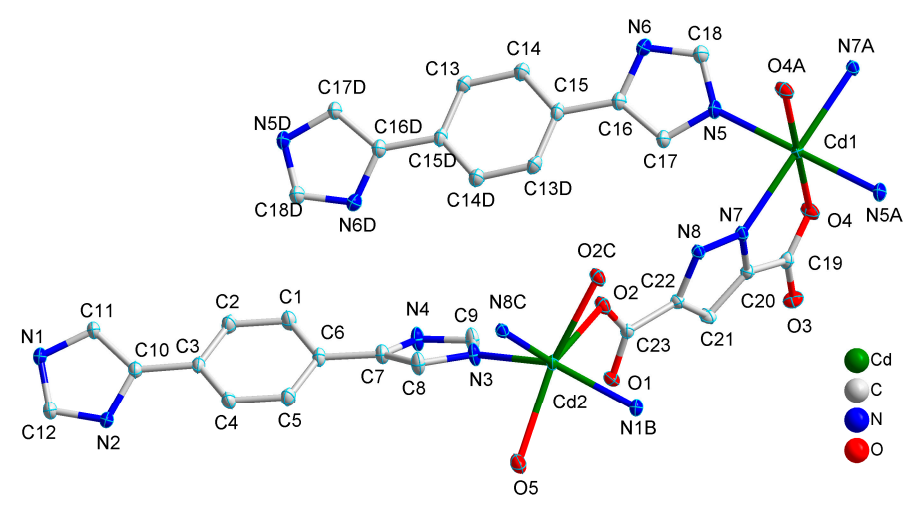

Figure 1. The coordination environment of $\mathrm{Cd}(\mathrm{II})$ ion in $\mathbf{1}$ with the ellipsoids drawn at the $30 \%$ probability level. The hydrogen atoms are omitted for clarity. Symmetry code: A $1-x,-y, 3-z$, $B-1+x, y, 1+z, C 1-x, 1-y, 2-z, D 2-x,-y, 2-z$. 
Table 1. Selected bond lengths $(\AA)$ and bond angles $\left(^{\circ}\right)$ for $\mathbf{1}$.

\begin{tabular}{|c|c|c|c|}
\hline Bond & $d$ & Bond & $d$ \\
\hline $\mathrm{Cd}(1)-\mathrm{N}(5)$ & $2.299(2)$ & $\mathrm{Cd}(1)-\mathrm{O}(4)$ & $2.3324(18)$ \\
\hline $\mathrm{Cd}(1)-\mathrm{N}(7)$ & $2.3449(19)$ & $\mathrm{Cd}(2)-\mathrm{N}(3)$ & $2.258(2)$ \\
\hline $\mathrm{Cd}(2)-\mathrm{N}(1) \mathrm{ii}$ & $2.245(2)$ & $\mathrm{Cd}(2)-\mathrm{N}(8){ }^{\mathrm{iii}}$ & $2.3473(19)$ \\
\hline $\mathrm{Cd}(2)-\mathrm{O}(2)$ & $2.4204(17)$ & $\mathrm{Cd}(2)-\mathrm{O}(5)$ & $2.481(2)$ \\
\hline Angle & $\omega$ & Angle & $\omega$ \\
\hline $\mathrm{N}(5){ }^{\mathrm{i}}-\mathrm{Cd}(1)-\mathrm{N}(5)$ & $180.000(1)$ & $\mathrm{N}(5){ }^{\mathrm{i}}-\mathrm{Cd}(1)-\mathrm{O}(4)$ & $86.21(8)$ \\
\hline $\mathrm{N}(5)-\mathrm{Cd}(1)-\mathrm{O}(4)$ & $93.79(8)$ & $\mathrm{O}(4)-\mathrm{Cd}(1)-\mathrm{O}(4)^{\mathrm{i}}$ & 180.0 \\
\hline $\mathrm{N}(5){ }^{\mathrm{i}}-\mathrm{Cd}(1)-\mathrm{N}(7)$ & 93.10(7) & $\mathrm{N}(5)-\mathrm{Cd}(1)-\mathrm{N}(7)$ & $86.90(7)$ \\
\hline $\mathrm{O}(4)-\mathrm{Cd}(1)-\mathrm{N}(7)$ & $73.27(6)$ & $\mathrm{O}(4)^{\mathrm{i}}-\mathrm{Cd}(1)-\mathrm{N}(7)$ & $106.73(6)$ \\
\hline $\mathrm{O}(4)-\mathrm{Cd}(1)-\mathrm{N}(7)^{\mathrm{i}}$ & $106.73(6)$ & $\mathrm{N}(7)-\mathrm{Cd}(1)-\mathrm{N}(7){ }^{\mathrm{i}}$ & $180.00(6)$ \\
\hline $\mathrm{N}(1){ }^{\mathrm{ii}}-\mathrm{Cd}(2)-\mathrm{N}(3)$ & $146.85(8)$ & $\mathrm{N}(1){ }^{\mathrm{ii}}-\mathrm{Cd}(2)-\mathrm{N}(8){ }^{\mathrm{iii}}$ & $116.08(8)$ \\
\hline $\mathrm{N}(3)-\mathrm{Cd}(2)-\mathrm{N}(8){ }^{\mathrm{iii}}$ & 92.92(7) & $\mathrm{N}(1)^{\mathrm{ii}}-\mathrm{Cd}(2)-\mathrm{O}(2)^{\mathrm{iii}}$ & $86.93(7)$ \\
\hline $\mathrm{N}(3)-\mathrm{Cd}(2)-\mathrm{O}(2){ }^{\mathrm{iii}}$ & $119.34(8)$ & 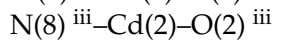 & $70.78(6)$ \\
\hline $\mathrm{N}(1){ }^{\mathrm{ii}}-\mathrm{Cd}(2)-\mathrm{O}(2)$ & $87.58(7)$ & $\mathrm{N}(3)-\mathrm{Cd}(2)-\mathrm{O}(2)$ & $86.32(7)$ \\
\hline $\mathrm{N}(8){ }^{\mathrm{iii}}-\mathrm{Cd}(2)-\mathrm{O}(2)$ & $128.20(6)$ & $\mathrm{O}(2){ }^{\mathrm{iii}}-\mathrm{Cd}(2)-\mathrm{O}(2)$ & $65.03(7)$ \\
\hline $\mathrm{N}(1){ }^{\mathrm{ii}}-\mathrm{Cd}(2)-\mathrm{O}(5)$ & $80.02(7)$ & $\mathrm{N}(3)-\mathrm{Cd}(2)-\mathrm{O}(5)$ & 81.14(8) \\
\hline $\mathrm{N}(8){ }^{\mathrm{iii}}-\mathrm{Cd}(2)-\mathrm{O}(5)$ & $96.39(7)$ & $\mathrm{O}(2){ }^{\mathrm{iii}}-\mathrm{Cd}(2)-\mathrm{O}(5)$ & $155.45(8)$ \\
\hline $\mathrm{O}(2)-\mathrm{Cd}(2)-\mathrm{O}(5)$ & $134.25(7)$ & & \\
\hline
\end{tabular}

Table 2. Hydrogen Bond Lengths $(\AA)$ and Bond Angles $\left({ }^{\circ}\right)$ for $\mathbf{1}$.

\begin{tabular}{ccccc}
\hline D-H $\cdots \mathbf{A}$ & $\mathbf{d}(\mathbf{D}-\mathbf{H})$ & $\mathbf{d}(\mathbf{H} \cdots \mathbf{A})$ & $\mathbf{d}(\mathbf{D} \cdots \mathbf{A})$ & $\angle$ DHA \\
\hline $\mathrm{O}(5)-\mathrm{H}(5 \mathrm{~W} 1) \cdots \mathrm{O}(4)^{\mathrm{a}}$ & 0.83 & 1.90 & $2.722(3)$ & $173(3)$ \\
$\mathrm{N}(2)-\mathrm{H}(2 \mathrm{~A}) \cdots \mathrm{O}(1)^{\mathrm{b}}$ & 0.8600 & 1.9100 & $2.738(3)$ & 160.00 \\
$\mathrm{~N}(4)-\mathrm{H}(4 \mathrm{~A}) \cdots \mathrm{O}(3)^{\mathrm{c}}$ & 0.8600 & 1.8900 & $2.744(3)$ & 176.00 \\
$\mathrm{~N}(6)-\mathrm{H}(6) \cdots \mathrm{O}(3)^{\mathrm{d}}$ & 0.8600 & 1.9200 & $2.745(3)$ & 161.00 \\
$\mathrm{C}(4)-\mathrm{H}(4) \cdots \mathrm{O}(1)^{\mathrm{b}}$ & 0.9300 & 2.5300 & $3.071(3)$ & 117.00 \\
$\mathrm{C}(12)-\mathrm{H}(12) \cdots \mathrm{O}(5)^{\mathrm{e}}$ & 0.9300 & 2.4900 & $3.033(3)$ & 117.00 \\
\hline
\end{tabular}

Symmetry codes: (a) $x, 1+y,-1+z$; (b) $1-x, 1-y, 1-z$; (c) $1-x,-y, 2-z$; (d) $1+x, y, z$; (e) $1+x, y,-1+z$.

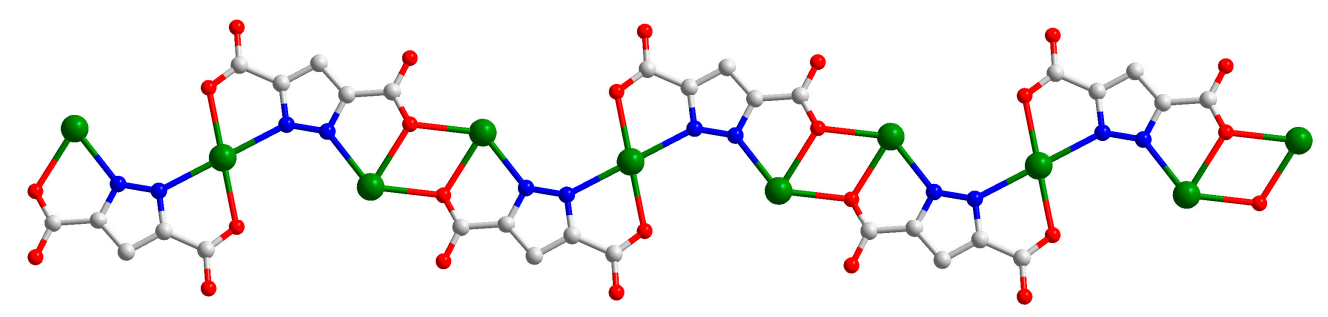

Figure 2. 1D chain structure of $\mathbf{1}$.

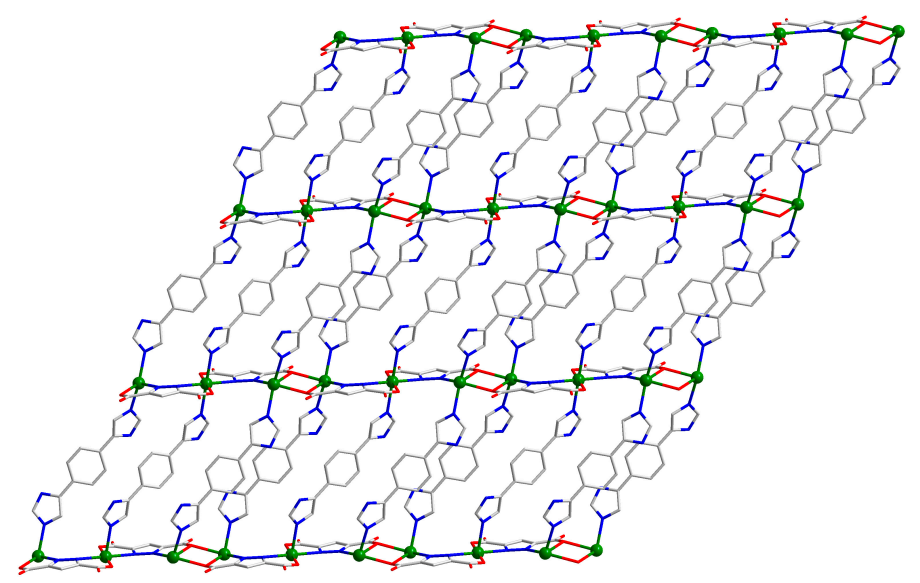

Figure 3. 2D layer structure of $\mathbf{1}$. 


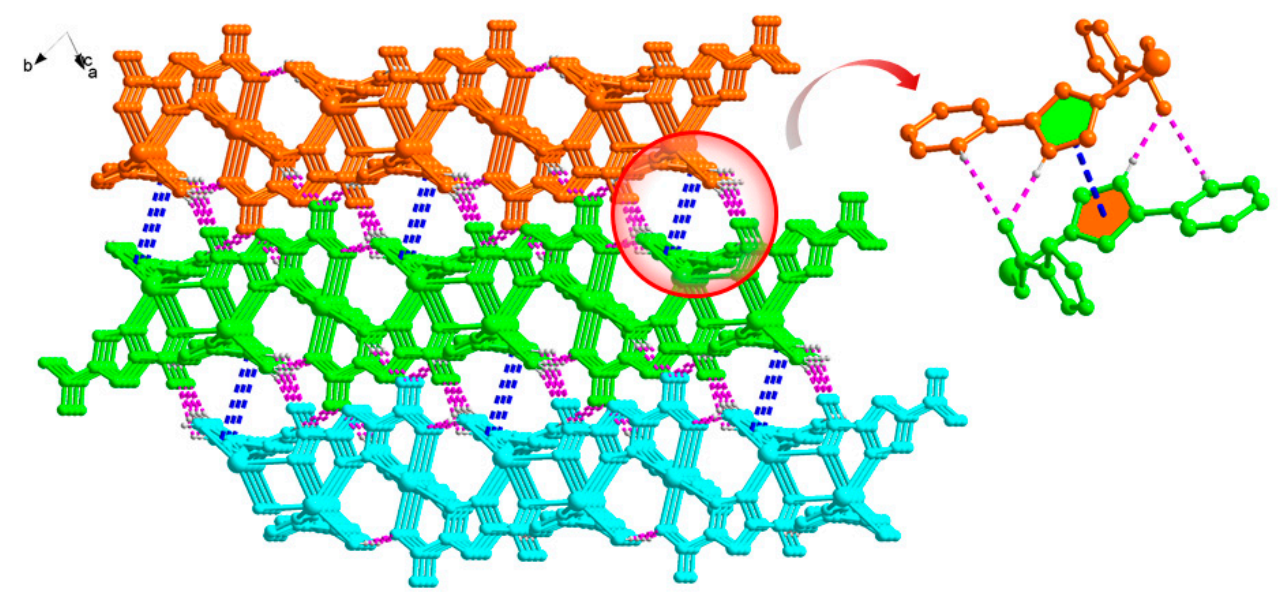

Figure 4. 3D supramolecular network structure of 1 linked by hydrogen bonding (pink dotted line) and $\pi \cdots \pi$ stacking interactions by a centroid-centroid distance of $3.86 \AA$ (blue dotted line).

\subsection{Thermal Analysis and Powder X-ray Diffraction Analysis}

Complex 1 was examined by thermogravimetric analysis (TGA) to investigate the thermal stability of supramolecular architecture in the $\mathrm{N}_{2}$ atmosphere from $25-750^{\circ} \mathrm{C}$, and the result is shown in Figure 5 . For 1, weight loss of $2.93 \%$ was observed in the temperature range of $80-105{ }^{\circ} \mathrm{C}$, which corresponds to the exclusion of coordinated water molecules (calcd $2.75 \%$ for 1 ), and further weight loss was observed at about $320{ }^{\circ} \mathrm{C}$, owing to the decomposition of the framework of 1 . A powder XRD experiment was carried out to confirm the phase purity of bulk sample, and the experimental pattern of the as-synthesized sample can be considered comparable to the corresponding simulated one, indicating the phase purity of the sample (Figure 6).

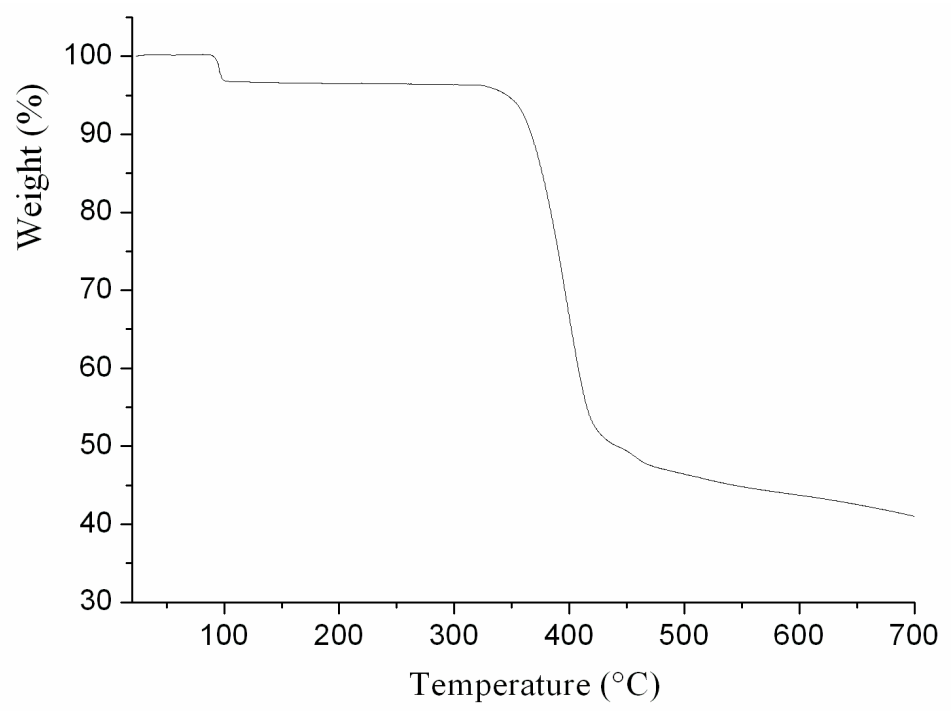

Figure 5. Thermal analysis curve of the complex $\mathbf{1 .}$ 


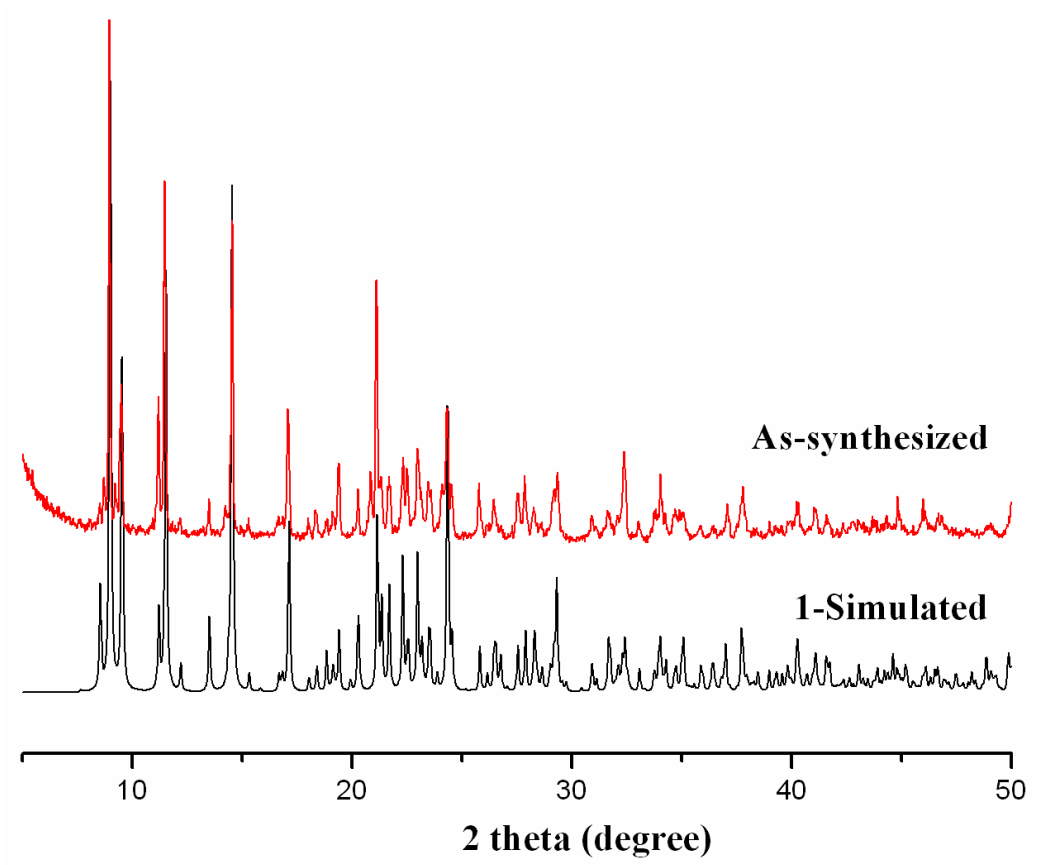

Figure 6. Simulated and experimental XRPD patterns of supramolecular polymer 1.

\subsection{Photoluminescent Property}

Inorganic-organic hybrid complexes, especially comprising the $\mathrm{d}^{10}$ closed-shell metal center and aromatic-containing system, have been reported to have the ability to adjust the emission through incorporation of metal centers, which impetus us to investigate the fluorescence property [22-24]. In this paper, the solid-state photoluminescent property of complex $\mathbf{1}$ as well as the organic ligands has been investigated in the solid state at room temperature as depicted in Figure 7. The free $\mathrm{H}_{2} \mathrm{~L}$ ligand shows intense emission band at $455 \mathrm{~nm}$ upon excitation at $342 \mathrm{~nm}$, which may be attributed to $\pi^{*} \rightarrow \pi$ transition of the intraligands because the aromatic nucleus of $\mathrm{H}_{2} \mathrm{~L}$ ligand are coplane [25]. However, the $\mathrm{H}_{3}$ pza nearly does not show fluorescence because the fluorescent emission of benzene-dicarboxylate ligands resulting from the $\pi^{*} \rightarrow \mathrm{n}$ transition is very weak compared with that of the $\pi^{*} \rightarrow \pi$ transition of the $\mathrm{H}_{2} \mathrm{~L}$ ligand, therefore, benzene-carboxylate ligands almost have no contribution to the fluorescent emission of as-synthesized coordination polymers $[16,26]$. It can be seen that complex 1 exhibits strong broad blue photoluminescence with emission maxima at $420 \mathrm{~nm}$ upon excitation at $338 \mathrm{~nm}$. By contrast with the free ligand, the emission bands of complex 1 are $35 \mathrm{~nm}$ blue-shifted. Such board emission bands may be tentatively assigned to ligand-to-metal charge transfer (LMCT) [27,28]. In addition, the Figure 7 shows that the luminescence intensity of $\mathbf{1}$ has increased compared with the free ligand under the same conditions, which may mainly originate from the coordination interactions between the metal $\mathrm{Cd}(\mathrm{II})$ atom and the ligand, which enhanced its conformational rigidity and then decreased the nonradiative energy loss [29]. 


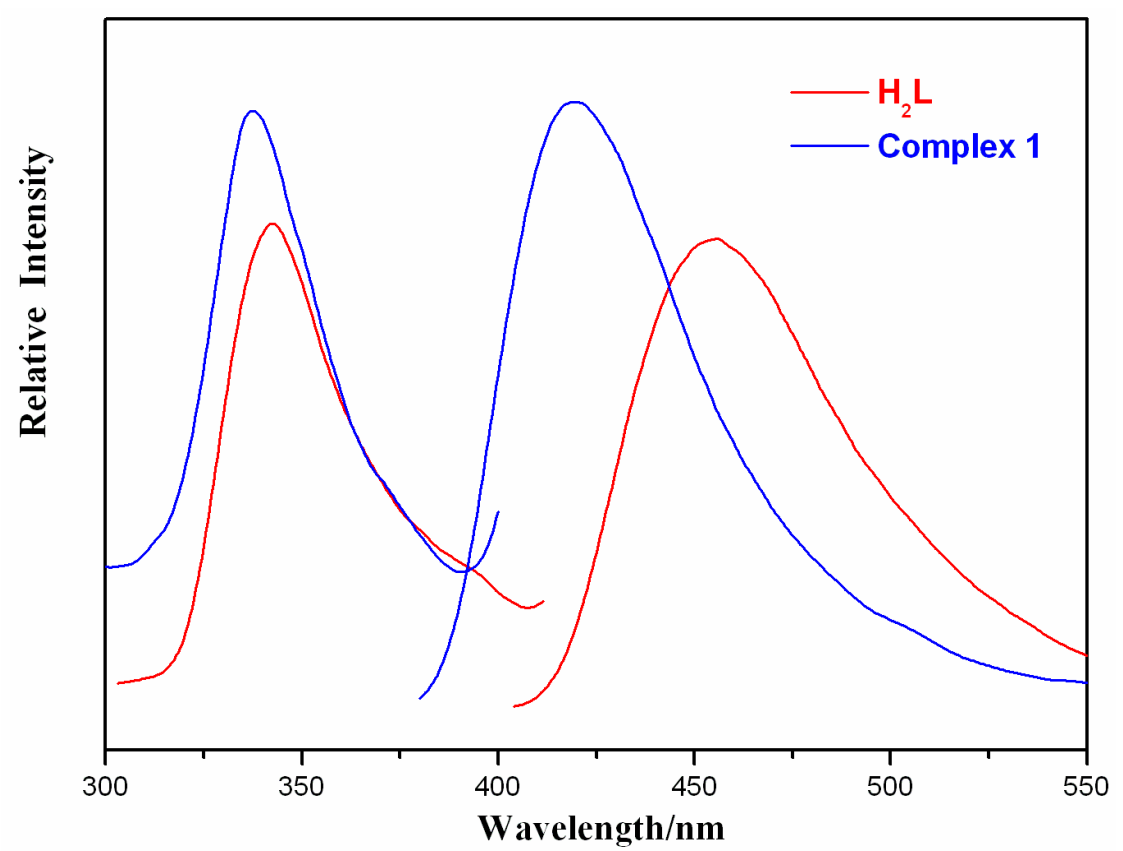

Figure 7. Solid-state photoluminescent spectra of $\mathbf{1}$ and $\mathrm{H}_{2} \mathrm{~L}$ ligand at room temperature.

\section{Experimental Section}

\subsection{Materials and Instrumentation}

All the chemicals and solvents used in this experiment were of reagent grade without further purification. Elemental analyses were performed on a Perkin-Elmer 240C Elemental Analyzer (PerkinElmer, Waltham, USA). IR spectra were recorded on a Bruker Vector 22 FT-IR spectrophotometer (Instrument Inc., Karlsruhe, Germany) using KBr pellets. Thermogravimetric analyses (TGA) were performed on a simultaneous SDT 2960 thermal analyzer (Thermal Analysis Instrument Inc., New Castle, DE, USA) under nitrogen with a heating rate of $10{ }^{\circ} \mathrm{C} \mathrm{min}-1$. Power X-ray diffraction (PXRD) patterns were measured on a Shimadzu XRD-6000 X-ray diffractometer (Shimadzu Corporation, Kyoto, Japan) with $\mathrm{CuK \alpha}(\lambda=1.5418 \AA)$ radiation at room temperature. The fluorescent spectra were measured using a Perkin Elmer LS-55B fluorescence spectrometer (PerkinElmer, Billerica, MA, USA).

\subsection{Synthesis of $\left[\mathrm{Cd}_{3}\left(\mathrm{H}_{2} \mathrm{~L}\right)_{3}(\mathrm{Pza})_{2}\left(\mathrm{H}_{2} \mathrm{O}\right)_{2}\right]_{n}(\mathbf{1})$}

A mixture of $\mathrm{H}_{2} \mathrm{~L}(0.021 \mathrm{~g}, 0.1 \mathrm{mmol}), \mathrm{H}_{3} \mathrm{Pza}(0.0308 \mathrm{~g}, 0.1 \mathrm{mmol}), \mathrm{CdCl}_{2} \cdot 2.5 \mathrm{H}_{2} \mathrm{O}(0.0228 \mathrm{~g}$, $0.1 \mathrm{mmol})$ and $\mathrm{NaOH}(0.004 \mathrm{~g}, 0.1 \mathrm{mmol})$ in $10 \mathrm{~mL} \mathrm{H}_{2} \mathrm{O}$ was sealed in a $20 \mathrm{~mL}$ Teflon-lined stainless steel container and heated at $180^{\circ} \mathrm{C}$ for $48 \mathrm{~h}$. Coloress block crystals of 1 were collected with a yield of $52 \%$ by filtration and washed with water and ethanol for several times. Anal. Calcd. (\%) for $\mathrm{C}_{46} \mathrm{H}_{36} \mathrm{~N}_{16} \mathrm{O}_{10} \mathrm{Cd}_{3}$ : $\mathrm{C}, 42.17 ; \mathrm{H}, 2.77 ; \mathrm{N}, 17.11$. Found (\%): C, 42.36; H, 2.92; N, 17.31. IR(KBr): 3371-2545(m), 1598(vs), 1551(vs), 1512(m), 1392(vs), 1298(m), 1190(m), 1171(m), 1129(s), 1059(w), 955(m), 859(s), 829(m), 788(s), 705(m), 650(m), 510(m) $\mathrm{cm}^{-1}$.

\subsection{Crystal Structure Determination}

The single crystal data of $\left[\mathrm{Cd}_{3}\left(\mathrm{H}_{2} \mathrm{~L}\right)_{3}(\mathrm{Pza})_{2}\left(\mathrm{H}_{2} \mathrm{O}\right)_{2}\right]_{\mathrm{n}}(\mathbf{1})$ was collected on a Bruker Smart APEX CCD diffractometer with graphite-monochromated MoK $\alpha$ radiation $(\lambda=0.71073 \AA)$ at $293(2) \mathrm{K}$. The structure was solved by direct method and refined by full-matrix least squares on $\mathrm{F}^{2}$ using the SHELX-97 program [30]. The hydrogen atoms were generated geometrically. The crystallographic data and structural refinement are listed in Table 3. 
Table 3. Crystallographic data and structure refinement for $\mathbf{1 .}$

\begin{tabular}{|c|c|}
\hline Empirical Formula & $\mathrm{C}_{46} \mathrm{H}_{36} \mathrm{~N}_{16} \mathrm{O}_{10} \mathrm{Cd}_{3}$ \\
\hline Formula weight & 1310.14 \\
\hline Temperature/K & $296(2)$ \\
\hline Crystal system & Triclinic \\
\hline Space group & $P-1$ \\
\hline$a / \AA$ & $9.5416(10)$ \\
\hline$b / \AA$ & $11.3868(12)$ \\
\hline$c / \AA$ & $12.8411(14)$ \\
\hline$\alpha /^{\circ}$ & $65.8260(10)$ \\
\hline$\beta /{ }^{\circ}$ & $77.4100(10)$ \\
\hline$\gamma /{ }^{\circ}$ & $80.1150(10)$ \\
\hline Volume $/ \AA^{3}$ & $1236.9(2)$ \\
\hline Z & 1 \\
\hline$\varrho_{\text {calc }} \mathrm{mg} / \mathrm{mm}^{3}$ & 1.759 \\
\hline$\mu / \mathrm{mm}^{-1}$ & 1.353 \\
\hline$S$ & 1.090 \\
\hline$F(000)$ & 648 \\
\hline Index ranges & $\begin{array}{l}-11 \leq h \leq 11 \\
-13 \leq k \leq 14 \\
-16 \leq l \leq 15\end{array}$ \\
\hline Reflections collected & 9658 \\
\hline Independent reflections & 5038 \\
\hline Data/restraints/parameters & $5038 / 2 / 348$ \\
\hline Goodness-of-fit on $F^{2}$ & 1.090 \\
\hline Final $R$ indexes $[\mathrm{I} \geq 2 \sigma(I)]$ & $R_{1}=0.0225, w R_{2}=0.0619$ \\
\hline Final $R$ indexes [all data] & $R_{1}=0.0259, w R_{2}=0.0639$ \\
\hline Largest diff. peak/hole / e $\AA^{-3}$ & $1.298 /-0.327$ \\
\hline
\end{tabular}

Crystallographic data for the structure reported in this paper has been deposited with the Cambridge Crystallographic Data Centre as supplementary publication Nos. CCDC 1554215 for 1. Copy of the data can be obtained free of charge on application to CCDC, 12 Union Road, Cambridge CB2 1EZ, UK (Fax: +44-1223-336-033; E-Mail: deposit@ccdc.cam.ac.uk).

\section{Conclusions}

In summary, we have successfully obtained a new coordination polymer $\left[\mathrm{Cd}_{3}\left(\mathrm{H}_{2} \mathrm{~L}\right)_{3}(\mathrm{Pza})_{2}\left(\mathrm{H}_{2} \mathrm{O}\right)_{2}\right]_{\mathrm{n}}$ (1) by the reaction of $\mathrm{Cd}$ (II) salt with mixed imidazole and carboxylate ligands. The $\mathrm{H}_{3}$ Pza was completely deprotonated to $\mathrm{pza}^{3-}$ anions that connected $\mathrm{Cd}(\mathrm{II})$ into infinite $1 \mathrm{D}$ chain structure. The adjacent $1 \mathrm{D}$ chains were further linked to form a $2 \mathrm{D}$ network by rigid ditopic $\mathrm{H}_{2} \mathrm{~L}$ ligands. Furthermore, the 3D coordination polymer was generated by the classic weak hydrogen bond and $\pi-\pi$ stacking interactions. Moreover, the complex 1 exhibits blue photoluminescence emission at $420 \mathrm{~nm}$ upon excitation at $338 \mathrm{~nm}$.

Acknowledgments: This project was supported by Natural Science Foundation of Fuyang (KJ2011B123).

Author Contributions: Zhu Mei-An and Shi Shan-Shan synthesize the organic compounds. Han Shuai-Shuai and Mei Jin synthesized the metal coordination polymers. Chen Shui-Sheng designed the method and guided the manuscript.

Conflicts of Interest: The authors declare no conflict of interest.

\section{References}

1. Furukawa, H.; Cordova, K.E.; O'Keeffe, M.; Yaghi, O.M. The chemistry and applications of metal-organic frameworks. Science 2013, 341, 974. [CrossRef] [PubMed]

2. Brenner, W.; Ronson, T.K.; Nitschke, J.R. Separation and selective formation of fullerene adducts within an $\mathrm{M}_{8}{ }_{8} \mathrm{~L}_{6}$ cage. J. Am. Chem. Soc. 2017, 139, 75-78. [CrossRef] [PubMed] 
3. Wang, W.; Yang, J.; Wang, R.; Zhang, L.; Yu, J.; Sun, D. Luminescent terbium-organic framework exhibiting selective sensing of nitroaromatic compounds (NACs). Cryst. Growth Des. 2015, 15, 2589-2592. [CrossRef]

4. Li, Y.W.; Yan, H.; Hu, T.L.; Ma, H.Y.; Li, D.C.; Wang, S.N.; Yao, Q.X.; Dou, J.M.; Xu, J.; Bu, X.H. Two microporous Fe-based MOFs with multiple active sites for selective gas adsorption. Chem. Commun. 2017, 53, 2394-2397. [CrossRef] [PubMed]

5. Chen, M.M.; Zhou, X.; Li, H.X.; Yang, X.X.; Lang, J.P. Luminescent two-dimensional coordination polymer for selective and recyclable sensing of nitroaromatic compounds with high sensitivity in water. Cryst. Growth Des. 2015, 15, 2753-2760. [CrossRef]

6. Li, D.S.; Wu, Y.P.; Zhao, J.; Zhang, J.; Lu, J.Y. Metal-organic frameworks based upon non-zeotype 4-connected topology. Coord. Chem. Rev. 2014, 261, 1-27. [CrossRef]

7. Zhou, D.D.; He, C.T.; Liao, P.Q.; Xue, W.; Zhang, W.X.; Zhou, H.L.; Zhang, J.P.; Chen, X.M. A flexible porous $\mathrm{Cu}(\mathrm{II})$ bis-imidazolate framework with ultrahigh concentration of active sites for efficient and recyclable $\mathrm{CO}_{2}$ capture. Chem. Commun. 2013, 49, 11728-11730. [CrossRef] [PubMed]

8. Hu, Z.; Deiberta, B.J.; Li, J. Luminescent metal-organic frameworks for chemical sensing and explosive detection. Chem. Soc. Rev. 2014, 43, 5815-5840. [CrossRef] [PubMed]

9. Férey, G. Hybrid porous solids: Past, present, future. Chem. Soc. Rev. 2008, 37, 191-214. [CrossRef] [PubMed]

10. Long, J.R.; Yaghi, O.M. The pervasive chemistry of metal-organic frameworks. Chem. Soc. Rev. 2009, 38, 1213-1214. [CrossRef] [PubMed]

11. Zhang, W.Q.; Zhang, W.Y.; Wang, R.D.; Ren, C.Y.; Li, Q.Q.; Fan, Y.P.; Liu, B.; Liu, P.; Wang, Y.Y. Effect of coordinated solvent molecules on metal coordination sphere and solvent-induced transformations. Cryst. Growth Des. 2017, 17, 517-526. [CrossRef]

12. Zhao, J.P.; Han, S.D.; Zhao, R.; Yang, Q.; Chang, Z.; Bu, X.H. Tuning the structure and magnetism of heterometallic sodium $(1+)$-cobalt(2+) formate coordination polymers by varying the metal ratio and solvents. Inorg. Chem. 2013, 52, 2862-2869. [CrossRef] [PubMed]

13. Zang, S.Q.; Dong, M.M.; Fan, Y.J.; Hou, H.W.; Mak, T.C.W. Four cobaltic coordination polymers based on 5-iodo-isophthalic acid: Halogen-related interaction and solvent effect. Cryst. Growth Des. 2012, 12, 1239-1246. [CrossRef]

14. Sapianik, A.A.; Zorina-Tikhonova, E.N.; Kiskin, M.A.; Samsonenko, D.G.; Kovalenko, K.A.; Sidorov, A.A.; Eremenko, I.L.; Dybtsev, D.N.; Blake, A.J.; Argent, S.P.; et al. Rational synthesis and investigation of porous metal-organic framework materials from a preorganized heterometallic carboxylate building block. Inorg. Chem. 2017, 56, 1599-1608. [CrossRef] [PubMed]

15. Zeng, W.; Jiang, J. Synthesis and crystal structures of two novel O, N-containing spiro compounds. Crystals 2016, 6, 69. [CrossRef]

16. Li, Y.W.; Ma, H.; Chen, Y.Q.; He, K.H.; Li, Z.X.; Bu, X.H. Structure modulation in Zn(II)-1,4-Bis(imidazol1-yl)benzene frameworks by varying dicarboxylate anions. Cryst. Growth Des. 2012, 12, 189-196. [CrossRef]

17. Chen, S.S.; Chen, M.; Takamizawa, S.; Chen, M.S.; Su, Z.; Sun, W.Y. Temperature dependent selective gas sorption of the microporous metal-imidazolate framework $[\mathrm{Cu}(\mathrm{L})]\left[\mathrm{H}_{2} \mathrm{~L}=1,4\right.$-di(1H-imidazol-4-yl) benzene]. Chem. Commun. 2011, 47, 752-754. [CrossRef] [PubMed]

18. Chen, S.S.; Chen, M.; Takamizawa, S.; Wang, P.; Lv, G.C.; Sun, W.Y. Porous cobalt(II)-imidazolate supramolecular isomeric frameworks with selective gas sorption property. Chem. Commun. 2011, 47, 4902-4904. [CrossRef] [PubMed]

19. Chen, S.S.; Sheng, L.Q.; Zhao, Y.; Liu, Z.D.; Qiao, R.; Yang, S. Syntheses, structures, and properties of a series of polyazaheteroaromatic core-based $\mathrm{Zn}$ (II) coordination polymers together with carboxylate auxiliary ligands. Cryst. Growth Des. 2016, 16, 229-241. [CrossRef]

20. Chen, S.S.; Qiao, R.; Sheng, L.Q.; Zhao, Y.; Yang, S.; Chen, M.M.; Liu, Z.D.; Wang, D.H. Cadmium(II) and zinc(II) complexes with rigid 1-(1H-imidazol-4-yl)-3-(4H-tetrazol-5-yl)benzene and varied carboxylate ligands. CrystEngComm 2013, 15, 5713-5725. [CrossRef]

21. Chen, S.S.; Liu, Q.; Zhao, Y.; Qiao, R.; Sheng, L.Q.; Liu, Z.D.; Yang, S.; Song, C.F. New metal-organic frameworks constructed from the 4-imidazole-carboxylate ligand: Structural diversities, luminescence, and gas adsorption properties. Cryst. Growth Des. 2014, 14, 3727-3741. [CrossRef]

22. Kreno, L.E.; Leong, K.; Farha, O.K.; Allendorf, M.; Van Duyne, R.P.; Hupp, J.T. Metal-organic framework materials as chemical sensors. Chem. Rev. 2012, 112, 1105-1125. [CrossRef] [PubMed] 
23. Guo, X.Z.; Zhang, Z.Y.; Li, Z.L.; Shi, S.S.; Chen, S.S. Crystals Synthesis, crystal structures, and properties of two coordination polymers built from imidazolyl and carboxylate ligands. Crystals 2017, 7, 73. [CrossRef]

24. Qiu, Y.C.; Li, Y.H.; Peng, G.; Cai, J.B.; Jin, L.M.; Ma, L.; Deng, H.; Zeller, M.; Batten, S.R. Cadmium metal-directed three-dimensional coordination polymers: In situ tetrazole ligand synthesis, structures, and luminescent properties. Cryst. Growth Des. 2010, 10, 1332-1340. [CrossRef]

25. Meng, F.; Zhang, M.; Shen, K.; Li, Y.; Zheng, H. A series of MOFs based on a triangular tri(4-pyridylphenyl)amine ligand combined with carboxylate or nitrate auxiliary ligands. Dalton Trans. 2015, 44, 1412-1419. [CrossRef] [PubMed]

26. Hua, J.A.; Zhao, Y.; Liu, Q.; Zhao, D.; Chen, K.; Sun, W.Y. Zinc(II) coordination polymers with substituted benzenedicarboxylate and tripodal imidazole ligands: Syntheses, structures and properties. CrystEngComm 2014, 16, 7536-7546. [CrossRef]

27. Li, L.N.; Wang, S.Y.; Chen, T.L.; Sun, Z.H.; Luo, J.H.; Hong, M.C. Solvent-dependent formation of Cd(II) coordination polymers based on a $C_{2}$-symmetric tricarboxylate linker. Cryst. Growth Des. 2012, 12, 4109-4115. [CrossRef]

28. Song, S.Y.; Song, X.Z.; Zhao, S.N.; Qin, C.; Su, S.Q.; Zhu, M.; Hao, Z.M.; Zhang, H.J. Syntheses, structures and physical properties of transition metal-organic frameworks assembled from trigonal heterofunctional ligands. Dalton Trans. 2012, 41, 10412-10421. [CrossRef] [PubMed]

29. Xu, J.; Bai, Z.S.; Chen, M.S.; Su, Z.; Chen, S.S.; Sun, W.Y. Metal-organic frameworks with six- and four-fold interpenetration and their photoluminescence and adsorption property. CrystEngComm 2009, 11, 2728-2733. [CrossRef]

30. Sheldrick, G.M. A short history of SHELX. Acta Cryst. 2008, 64, 112-122. [CrossRef] [PubMed]

(C) 2017 by the authors. Licensee MDPI, Basel, Switzerland. This article is an open access article distributed under the terms and conditions of the Creative Commons Attribution (CC BY) license (http://creativecommons.org/licenses/by/4.0/). 